\title{
Pediatric dental treatment: manifestations of stress in patients, mothers and dental school students
}

\section{Tratamento odontopediátrico: manifestações de estresse em pacientes, mães e alunos de Odontologia}

\author{
Cármen Lúcia Cardoso* \\ Sônia Regina Loureiro** \\ Paulo Nelson-Filho***
}

\begin{abstract}
The aim of this study was to compare a group of children with high levels of anxiety during dental treatment who required physical restraint (group 1) to a group of children who collaborated with treatment (group 2). Child stress and its relationship with the manifestations of stress of the mothers and the dental students were assessed. The following psychological evaluation techniques were applied: the Child Stress Scale, the Rutter Parent Scale A2, Dental Fear Survey, and Lipp Stress Symptoms Inventory for Adults. Group 1 presented higher stress indicators, and emotional and behavior difficulties than group $2(\mathrm{p} \leq 0.01)$. The stress indicators and the dental fear presented by mothers from group 1 were higher than that from group $2(\mathrm{p} \leq 0.01)$. The dental students who treated the children from both groups presented high stress levels. We conclude that the difficulties experienced by the child and the mother, associated to the student's diminished ability to control the situation, may negatively influence the perception that the child has of dental treatment. A set of factors related to the children, mothers or dental students may cause poor collaboration during the dental treatment.
\end{abstract}

DESCRIPTORS: Pediatric dentistry; Behavioral medicine; Dental anxiety; Stress.

\begin{abstract}
RESUMO: O objetivo deste estudo foi comparar um grupo de crianças com altos níveis de ansiedade frente ao tratamento odontopediátrico que necessitaram de contenção fisica (grupo 1) a um grupo de crianças que colaboraram com o atendimento (grupo 2). Para tal, o estresse infantil e suas relações com manifestações de estresse de acompanhantes/mães e dos alunos de Odontologia foram avaliados. Procedeu-se à aplicação das técnicas: Escala de Estresse Infantil, Escala Comportamental Infantil A2 de Rutter, "Dental Fear Survey" e Inventário de Sintomas de Estresse para Adultos de Lipp. O grupo 1 apresentou indicadores mais elevados de estresse e de dificuldades emocionais e comportamentais que o grupo $2(\mathrm{p} \leq 0,01)$. Os indicadores de estresse e de medo odontológico apresentados pelas mães do grupo 1 foram maiores que os apresentados pelas mães do grupo 2 ( $p \leq 0,01)$. Os alunos que atenderam as crianças dos dois grupos apresentaram elevados niveis de estresse. Conclui-se que as dificuldades vivenciadas pela criança e pelo acompanhante associadas à pouca capacidade do aluno para controlar a situação podem estar influenciando a percepção que a criança tem do tratamento odontológico. Um conjunto de fatores ligados às crianças, aos acompanhantes e aos alunos interferem nas manifestações de comportamentos pouco colaboradores no tratamento odontológico.
\end{abstract}

DESCRITORES: Odontopediatria; Medicina do comportamento; Ansiedade ao tratamento odontológico; Estresse.

\section{INTRODUCTION}

Anxiety and stress are frequently related to dental treatment because both physiological stimuli, such as pain, and emotional reactions to this treatment are seen by many patients as threatening to their welfare ${ }^{5}$. Stress and anxiety have been related to avoidance of or flight from dental treatment, even when treatment is extremely necessary, thus affecting the oral health of the individual ${ }^{2,4,6}$.
Giron $^{8}$ (1988) observed that pediatric patients do not have a choice and are taken by their parents for dental treatment. These patients show their fear by crying, refusing to open their mouth, kicking and throwing up to avoid treatment.

Anxiety towards dental treatment has been associated to multifactor etiology, influenced by internal individual aspects, living environment and the dental treatment situation ${ }^{6,7,14}$. Among these

\footnotetext{
* Professor, School of Philosophy, Sciences and Letters of Ribeirão Preto, Department of Psychology and Education; **Professor, School of Medicine of Ribeirão Preto; ***Professor, Department of Pediatric Dentistry, School of Dentistry of Ribeirão Preto University of São Paulo.
} 
Cardoso CL, Loureiro SR, Nelson-Filho P. Pediatric dental treatment: manifestations of stress in patients, mothers and dental school students. Braz Oral Res 2004;18(2):150-5.

factors, the importance of the child's relationship with the mother is reported by Corkey, Freeman ${ }^{3}$ (1994), due to the double role of this relationship that influences the child's psychological development and his/her ability to make dental care difficult. These aspects were also emphasized by Venham et al. ${ }^{19}$ (1979), who reported that the form in which the child tolerates stress and the ability to deal with stress seems to be eased when their home is structured, the mothers are understanding and self-confident and the fathers impose limits.

Another important factor is the importance of the first relationship with the dentist ${ }^{14}$. One of the main objectives in pediatric dental care is to develop positive attitudes in children facing treatment, because it is more difficult and expensive to change anxious behaviors. It is important to note that dental practice is associated with high levels of stress not only for patients and their parents but also for the dentist ${ }^{15}$.

Dental students perform their first clinical activities in dental school under the supervision and guidance of a professor ${ }^{10,15,18}$. The dental student, as well as the dental professional, is submitted to various factors that are potentially stressful. Dental treatment of a child requires not only technical preparation, but also knowledge of and ability to deal with this phase of development using special management techniques ${ }^{11}$. Tedesco ${ }^{18}$ (1986) and Newton $^{15}$ (1994) reported that the levels of stress experienced by students are related to a decrease in their performance during undergraduate school, which may directly affect their behavior in clinical practice. The refusal of a child to allow dental treatment, with non-collaborating behavior, associated with limited practical experience of the student, leads to an impasse for all those involved.

The aim of the present study was to compare a group of children with no special cognitive needs who presented a high level of anxiety for dental treatment and required physical restraint for this procedure to a group of children that collaborated with dental treatment. Therefore, the following hypotheses were analyzed: a) Do the children who require physical restraint present more stress manifestations and behavior difficulties than those who do not require restraint?; b) Were the parents of the children who required physical restraint more stressed and fearful of dental treatment compared to the parents of the children who collaborated?; c) Were the students who treated the children who required physical restraint more stressed during the dental treatment compared to those who treated the children who collaborated?

\section{MATERIAL AND METHODS}

This study was carried out at the Pediatric Dentistry Clinic of the Dental School of Ribeirão Preto (FORP-USP), under routine clinical conditions, after approval by the Ethics Committee (process \#1012299).

\section{Subjects}

Children - Initially, one hundred children were evaluated and 27 children (6-12 years old) required physical restraint for dental treatment, based on data observed in the first six sessions. Total or partial immobilization of the child by a dental assistant, the mother, either by arm or body restraints (papoose board) was used only after written consent was obtained from the parent or guardian. Exclusion criteria were delayed cognitive development (evaluated by specific tests), congenital malformation, and diagnosed or treated physiological or neurological problems. Children previously hospitalized because of health problems or those who did not live with their biological family were also excluded from this study.

Thus, from these 27 children, only 20 who needed physical restraint fit the pre-established criteria. They presented intense anxiety towards dental treatment and did not collaborate with procedures (group 1; 6-12 years old, 11 males, 9 females). Based on demographic characteristics of age and sex of these children, a group of 20 children who collaborated with treatment and did not require restraint formed group 2 .

All children involved in this study where submitted to low-invasive dental procedures (prophylaxis) and invasive procedures (restoration and endodontic treatment).

Parents from groups 1 and 2 - All parents were mothers. The average age was 33 years old (range, 23-43 years) and the degree of schooling varied from first grade to incomplete university education. When comparing the different characteristics between the parents from both groups, there was no statistically significant difference of age, education level or time of the last dental office visit (Mann-Whitney test; $\mathrm{p} \leq 0.05$ ).

Dental students - The 35 students who treated the children from groups 1 and 2 were from the $4^{\text {th }}$ year of the dental course at the University of 
Cardoso CL, Loureiro SR, Nelson-Filho P. Pediatric dental treatment: manifestations of stress in patients, mothers and dental school students. Braz Oral Res 2004;18(2):150-5.

São Paulo, School of Dentistry of Ribeirão Preto. Of these students, 5 treated children included in both groups or more than one child in the same group. No significant statistical differences were found among these students. Their average age was 21 years (range, 20-25 years) and there was no statistically significant difference when comparing both groups (Mann-Whitney test; $\mathrm{p} \leq 0.05$ ). For the variable sex, the chi-squared test was applied and there was also no statistically significant difference between groups, with $75 \%$ females treating group 1 and $60 \%$ treating group 2 . All students had at least 2 treatment sessions with the children.

\section{Instruments of psychological evaluation used to collect data}

- Child Stress Scale (CSS): validated by Lipp, Lucarelli $^{13}$ (1998), based on the Selye ${ }^{17}$ (1956) stress scale model. This scale evaluates 35 items of child stress using a Likert scale with a 5-point scoring system.

- Rutter ${ }^{16}$ (1981) Parent Scale A2: standardized by Graminha ${ }^{9}$ (1994). This scale evaluates behavioral and emotional problems of children with 36 items divided into three topics: problems of health, habits and behavior.

- Dental Fear Survey: validated for adults in Brazil by Cesar et al. ${ }^{2}$ (1993). This survey evaluates the level of fear of dental treatment and contains 20 items using a Likert scale with a 5-point scoring system.

- Lipp Stress Symptoms Inventory for Adults (LSSI): standardized in Brazil by Lipp ${ }^{12}$ (2000). This inventory evaluated stress symptoms, the type of symptom (physical and psychological), and the phase in which it is found: alert, resistance and exhaustion.

\section{Data collection}

The children were assessed individually for stress in one session of $25 \mathrm{~min}$. The mothers were interviewed regarding the child's behavior and assessed in terms of stress and fear levels individually, face to face, in one 40-min session.

The assessment of the dental students' stress was performed collectively in the classroom.

\section{Statistical analysis}

The data were analyzed with a non-parametric test comparing the groups with the different variables. The Mann-Whitney test was performed for the comparison of groups using the mean values from each group for the following instruments: Rutter Parent Scale A2, Child Stress Scale, Lipp Stress Symptom Inventory and Dental Fear Survey. The chi-squared test was used to compare data from the stress scales $(\mathrm{p} \leq 0.05)$. Univariate and multivariate regression analyses were used to evaluate the interaction among variables.

\section{RESULTS}

The results of the children's behavior from both groups obtained by the Rutter Parent Scale A2 are reported in Table 1 .

Statistically significant differences were observed between both groups of children for the total score, and the health and behavior scores. No significant differences were observed for the habit category. Group 1 children presented more behavior difficulties than group 2 children. The normative data of the Scale for the Brazilian population and the cut-off point relative to the total score above 16 points suggest the need for psychological or psychiatric care for the child ${ }^{9}$. A score greater than the cut-off was found for $65 \%$ of group 1 children and $20 \%$ of the children of group 2 (chisquared test; $\mathrm{p} \leq 0.01$ ).

The results related to stress manifestations for each group of children, mothers and students are presented in Table 2.

The children from group 1 presented a significantly higher total score than group 2 , indicating a higher number of stress answers. The mothers of group 1 children also presented a higher number of stress indicators when compared to group 2 mothers regarding physical and psychological symptoms in all stress test phases.

The results obtained were compared with the normative data of the Lipp Stress Symptoms Inventory for Adults for mothers and dental students (Table 3 ). The mothers of the children of group 1 presented a significantly higher percentage of

TABLE 1 - Mean score of children's behavior from both groups obtained by the Rutter Parent Scale A2.

\begin{tabular}{l|c|c|c}
\hline \hline \multicolumn{1}{c|}{ Scale } & Group 1 & Group 2 & Comparison \\
\hline Total score & 22.50 & 10.50 & $1>2^{* *}$ \\
\hline Health & 3.00 & 2.00 & $1>2^{*}$ \\
\hline Habits & 1.50 & 1.00 & $1=2$ \\
\hline Behavior & 17.00 & 8.00 & $1>2^{* *}$ \\
\hline
\end{tabular}

Mann-Whitney test, ${ }^{*} \mathrm{p}$-value $\leq 0.05,{ }^{* *} \mathrm{p}$-value $\leq 0.01$. 
Cardoso CL, Loureiro SR, Nelson-Filho P. Pediatric dental treatment: manifestations of stress in patients, mothers and dental school students. Braz Oral Res 2004;18(2):150-5.

TABLE 2 - Manifestations of stress in children, mothers and dental students, reported as mean score.

\begin{tabular}{|c|c|c|c|c|}
\hline & Stress & Group 1 & Group 2 & Comparison \\
\hline Children $^{\mathrm{a}}$ & Total score & 53.00 & 38.00 & $1>2^{*}$ \\
\hline \multirow{5}{*}{ Mothers $^{b}$} & Physical symptoms & 8.50 & 2.50 & $1>2^{*}$ \\
\hline & Psychological symptoms & 10.50 & 5.00 & $1>2^{*}$ \\
\hline & Alert phase & 3.00 & 1.00 & $1>2^{*}$ \\
\hline & Resistance phase & 8.00 & 3.00 & $1>2^{*}$ \\
\hline & Exhaustion phase & 8.00 & 3.00 & $1>2^{*}$ \\
\hline \multirow{5}{*}{ Students $^{\mathrm{b}}$} & Psychological symptoms & 4.00 & 5.50 & $1=2$ \\
\hline & Psychological symptoms & 5.50 & 6.00 & $1=2$ \\
\hline & Alert phase & 1.50 & 2.00 & $1=2$ \\
\hline & Resistance phase & 4.00 & 4.00 & $1=2$ \\
\hline & Exhaustion phase & 5.00 & 5.00 & $1=2$ \\
\hline
\end{tabular}

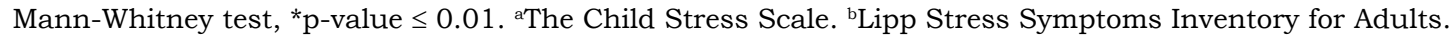

TABLE 3 - Percentage of mothers and students with stress compared to normative data ${ }^{12}$.

\begin{tabular}{|c|c|c|c|c|c|}
\hline & Stress & Group $1(\%)$ & Group $2(\%)$ & $\mathrm{p}$ & Comparison \\
\hline \multirow{6}{*}{ Mothers } & Presence & 80 & 35 & \multirow{2}{*}{0.01} & $1>2^{*}$ \\
\hline & Absence & 20 & 65 & & $1>\mathrm{N}, 2<\mathrm{N}$ \\
\hline & \multicolumn{3}{|c|}{ Presence of stress } & & \\
\hline & Alert phase & 0 & 0 & & \\
\hline & Resistance phase & 80 & 35 & & \\
\hline & Exhaustion phase & 0 & 0 & & \\
\hline \multirow{6}{*}{ Students } & Presence & 65 & 75 & \multirow{2}{*}{0.73} & $1=2$ \\
\hline & Absence & 35 & 25 & & 1 and $2>\mathrm{N}$ \\
\hline & \multicolumn{3}{|c|}{ Presence of stress } & & \\
\hline & Alert phase & 0 & 0 & & \\
\hline & Resistance phase & 60 & 75 & & \\
\hline & Exhaustion phase & 5 & 0 & & \\
\hline
\end{tabular}

Chi-squared test, *p-value $\leq 0.01 . \mathrm{N}=$ normative data.

stress than the mothers of the children of group 2 , especially in the resistance phase. There were no statistically significant differences between groups for the students' stress levels. However, most of the students presented higher stress levels than normative data.

In the Dental Fear Survey, the mothers from group 1 presented a significantly greater mean (53.5; $\mathrm{p} \leq 0.01)$ compared to group 2 mothers (38.0). According to the normative data (cutoff $\geq 60$ ) of the Dental Fear Survey, $40 \%$ of the mothers from group 1 presented high fear indicators during dental treatment compared to $5 \%$ of the mothers from group 2 (Fisher's exact test; $\mathrm{p} \leq 0.01)$.
The model of logistic regression (Table 4) was applied to all variables with values of $p<0.20$ in the univariant analysis (children: total score of stress and behavioral manifestations; mothers: total score of dental fear, physical and psychological symptoms, and phases of stress; students: physical and psychological symptoms and phases of stress). There was a significant association between the variable of physical restraint and the total score of stress for the child, and psychological symptoms of stress and total score of dental fear for the mother.

The percentage of correct classification of inclusion in groups 1 and 2 was obtained by the model of these three variables, which correctly 
Cardoso CL, Loureiro SR, Nelson-Filho P. Pediatric dental treatment: manifestations of stress in patients, mothers and dental school students. Braz Oral Res 2004;18(2):150-5.

TABLE 4 - Results of multivariate logistic regression analysis - final model - presenting the odds ratio, 95\% confidence interval $(95 \% \mathrm{CI})$ and values of $\mathrm{p}$.

\begin{tabular}{l|c|c|c}
\hline \hline \multicolumn{1}{c|}{ Variables } & Odds ratio & $95 \%$ CI & $\mathrm{p}$ \\
\hline Total score of child stress & 0.942 & $0.991-0.894$ & 0.022 \\
\hline Psychological symptoms of stress, mothers & 0.841 & $0.998-0.708$ & 0.048 \\
\hline Total score dental fear, mothers & 0.949 & $0.995-0.904$ & 0.031 \\
\hline \hline
\end{tabular}

identified $82.1 \%$ of the subjects of both groups. Among the isolated variables, the total score of fear of dental treatment (62.3\%) presented the best discrimination.

\section{DISCUSSION}

The presence of stress, and behavior and emotional problems in children requiring physical restraint can cause intense anxiety manifestations leading to difficulty for pediatric dental treatment, considering that perception of pain and fear is increased in stressed patients ${ }^{5}$. According to Lipp, Lucarelli ${ }^{13}$ (1998), patients who experience stress can present aggressive behavior to relieve anxiety.

The manifestations of stress in children and their emotional and behavior difficulties before dental treatment may influence their perception and manifestations in this specific situation. The methodology used in this study (selection of patients without a previous history of psychological and/or psychiatric treatment, children with mean cognitive development, and children at least 6 years old because there is increased tolerance to dental treatment at this age) indicated the need to consider behavior as an important element in dental treatment with implications for techniques and interaction.

The majority of mothers whose children needed physical restraint showed high stress manifestations. The predominant stage of stress was the resistance phase, which characterizes a permanent stress experience ${ }^{17}$. Thus, the dental treatment situation for these children and their mothers cannot be considered as leading to stress, but can be considered as an additional stress factor.

The indicators of stress shown by mothers whose children needed physical restraint were mainly psychological in nature and were characterized as anxiety, irritation, emotional hypersensitivity, lack of self confidence and little capacity to deal with their children's difficulties.
The association between stress levels of mothers whose children needed physical restraint and the high anxiety behavior of these children suggests an overwhelming situation for the mothers, minimizing conditions for supporting their children's needs. This is in agreement with Venham et al. ${ }^{19}$ (1979) and Corkey, Freeman ${ }^{3}$ (1994).

Considering the discriminative potential of the fear indicators and the results of this variable for the mothers whose children needed physical restraint, it is possible that the mother's attitudes and feelings about dental treatment could influence the child's perception of treatment. It is important to note that dental treatment anxiety is learned and develops through observation of, identification with, or its suggestion by role models ${ }^{3,6,7,14}$.

The majority of students who performed treatment presented above normal stress indicators, especially in the resistance phase (permanent stress and weakened organism). This is in agreement with other authors ${ }^{10,15,18}$, who have reported that the dental student is under many potential stress factors, including the relationship with patients who do not collaborate, do not accept treatment, or are very anxious about treatment.

The application of the model of logistic regression showed the association between the behavior of non-collaboration by the children and the stress scores of the children, and the manifestations of stress and dental fear of the mothers. The association of the Dental Fear Survey and the Inventory of Stress Symptoms applied to the mothers and the Child Stress Scale applied to the children correctly identified the children who would require physical restraint in $82.1 \%$ of the cases. It is important to note that the manifestations of stress in the students did not significantly affect this model.

The treatment of anxious children can be an extra stress factor because the student is more vulnerable and his ability to face and manage the situation is decreased. He is less able to meet and respond to the demands of the non-collaborating child and their mothers, who are also more 
Cardoso CL, Loureiro SR, Nelson-Filho P. Pediatric dental treatment: manifestations of stress in patients, mothers and dental school students. Braz Oral Res 2004;18(2):150-5.

stressed and have higher indicators of dental fear. The difficulties experienced by the child and the mother, associated with the student's diminished ability of controlling the situation, may negatively influence the perception that the child has of dental treatment, increasing the child's anxiety and thus, increasing the student's anxiety. We agree with Alwin et al. ${ }^{1}$ (1994) when he states that the emotional and physical condition of the dentist affects the perception of the child in this situation.

\section{CONCLUSION}

The group of children who required physical restraint for dental treatment (group 1) presented

\section{REFERENCES}

1. Alwin N, Murray JJ, Niven N. The effect of children's dental anxiety on the behaviour of a dentist. Int J Paediatr Dent 1994;4:19-24.

2. Cesar J, de Moraes AB, Milgrom P, Kleinknecht RA. Cross validation of a Brazilian version of the Dental Fear Survey. Community Dent Oral Epidemiol 1993;21:148-50.

3. Corkey B, Freeman R. Predictors of dental anxiety in sixyear-old children: findings from a pilot study. ASDC J Dent Child 1994;61:267-71.

4. de Moraes AB, Milgrom P, Tay KM, Costa SM. Prevalence of dental fear in Brazilian high school students in São Paulo state. Community Dent Oral Epidemiol 1994;22:114-5.

5. Eli I. Oral psychophysiology: stress, pain and behavior in dental care. Florida: CRC Press; 1992.

6. Eli I, Uziel N, Bath R, Kleinhauz M. Antecedents of dental anxiety: learned responses versus personality traits. Community Dent Oral Epidemiol 1997;25:233-7.

7. Freeman RE. Dental anxiety: a multifactorial aetiology. $\mathrm{Br}$ Dent J 1985;159:406-8.

8. Giron MCC. Fundamentos psicológicos da prática odontológica. Porto Alegre: D.C. Luzzatto; 1988.

9. Graminha SSV. A escala comportamental infantil de Rutter A2: estudos de adaptação e fidedignidade. Estudos de Psicol 1994;11:34-42.

10. Grandy TG, Westerman GH, Combs CE, Turner $\mathrm{CH}$. Perceptions of stress among third-year dental students. J Dent Educ 1989;53:718-21. more behavior and emotional problems and higher stress levels than the children who collaborated with treatment (group 2). These children also presented indicators of the need for psychological or psychiatric treatment. The mothers of these children presented higher stress and fear indicators. This suggests difficulties of both the children and their mothers in dealing with dental treatment, which can increase stress during treatment.

It is necessary to perform new studies on the impact of learning how to deal with stress of children, mothers and students.

11. Kuhn BR, Allen KD. Expanding child behavior management technology in pediatric dentistry: a behavioral science perspective. Pediatr Dent 1994;16:13-7.

12. Lipp MEM. Inventário de Sintomas de Stress para Adultos de Lipp (ISSL) - manual. São Paulo: Casa do Psicólogo; 2000.

13. Lipp MEN, Lucarelli MDM. Escala de stress infantil ESI - manual. São Paulo: Casa do Psicólogo; 1998.

14. Milgrom P, Weinstein P, Getz T. Treating fearful dental patients. $2^{\text {nd }}$ ed. Washington: University of Washington in Seattle; 1995.

15. Newton JT, Baghaienaini F, Goodwin SR, Invest J, Lubbock M, Marouf Saghakhaneh N. Stress in dental school: a survey of students. Dent Update 1994;21:1624.

16. Rutter M, Tizard J, Whitmore K. Education, health and behavior. Huntington: Krieger; 1981.

17. Selye H. The stress of life. New York: McGraw-Hill; 1956.

18. Tedesco LA. A psychosocial perspective on the dental educational experience and student performance. J Dent Educ 1986;50:601-5.

19. Venham LL, Murray P, Gaulin-Kremer E. Personality factors affecting the preschool child's response to dental stress. J Dent Res 1979;58:2046-51.

Received for publication on Oct 17, 2003 Sent for alterations on Jan 13, 2004 Accepted for publication on Mar 11, 2004 